Peer review: This article has been subject to a double blind peer review process

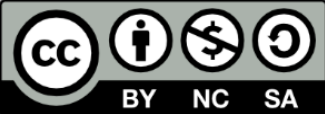

(C) Copyright: The Authors. This article is issued under the terms of the Creative Commons Attribution NonCommercial Share Alike License, which permits use and redistribution of the work provided that the original author and source are credited, the work is not used for commercial purposes and that any derivative works are made available under the same license terms.

\section{Myths of Male Same-Sex Love in the Art of the Italian Renaissance}

\section{Ann Haughton*}

Art History, University of Warwick

*Correspondence: ann.haughton@warwick.ac.uk

\begin{abstract}
Visual culture has much to contribute to an understanding of the history of sexuality. Yet, to date, the depiction of pederasty in the art of the Renaissance has not been covered adequately by dominant theoretical paradigms. Moreover, the interpretive approach of traditional art historical discourse has been both limited and limiting in its timidity toward matters concerning the representation of sexual proclivity between males. This article will address the ways in which Italian Renaissance artistic depictions of some mythological narratives were enmeshed with the period's attitudes toward sexual and social relationships between men.
\end{abstract}

Particular attention is paid here to the manner in which, under the veneer of a mythological narrative, certain works of art embodied a complex set of messages that encoded issues of masculine behaviour and performance in the context of intergenerational same-sex erotic relationships. The primary case studies under investigation for these concerns of gender and sexuality in this particular context are Benvenuto Cellini's marble Apollo and Hyacinth (1545), and Giulio Romano's drawing of Apollo and Cyparissus (1524). By incorporating pictorial analysis, social history, and gender and sexuality studies, new possibilities will be offered for evaluating these artworks as visual chronicles of particular sexual and cultural mores of the period. Furthermore, this article will consider how visual representation of these mythic narratives of erotic behaviour between males conformed to the culturally defined sexual and social roles relating to the articulation of power that permeated one of the greatest milestones in art history.

Keywords: Italian Renaissance art, art history, Apollo and Hyacinth, Apollo and Cyparissus, pederasty, sexuality

\section{Introduction}

Art was a fundamental part of the history of the Italian Renaissance, and visual images were not only creations of the individuals who designed and executed them but also of the society which produced these 
creators. Yet the common practice of pederasty, or male same-sex desire between a youth and an older man, has never mapped easily onto traditional notions concerned with representations of love and desire in the discursive field of art history (see Saslow, 1989; Ruggiero, 1985). ${ }^{1}$

Pederasty, as a formal bond between an adult man and an adolescent boy, which consisted of loving and often sexual relations has historically existed in a variety of forms and practices within different cultures, including ancient Greece and Renaissance Italy. Whilst pederasty existed in these cultures, attitudes were not entirely uniform. It was regarded as an erotic and pedagogic institution in ancient Greece, a more debated issue in Roman culture and a common phenomenon in Renaissance Florence. ${ }^{2}$ In these cultures, the love by men for adolescent males was regarded as a fundamental aspect of human experience. Surviving art and literature indicate that such feelings between adult higher class males were rare, and there is no evidence that pre-pubescent boys were the subject of interest (see Downing, 1990: 146-59; Lear and Cantarella, 2009: 139-64).

As an erotic and educational custom, pederasty was most commonplace among the upper classes as a means of teaching the young and conveying to them important cultural values such as courage, respect and restraint. Whilst sociological approaches to the historical study of gender, sexuality and identity in society and culture have become increasingly discursive in the last few decades, art historians still remain hesitant in expanding their purview beyond perceived Renaissance heterosexual 'norms'.

In the expansive study of the history of Renaissance art, there has been rare acknowledgement of the manner in which certain works of art can be used as a visual chronicle of how numerous individuals lived at variance with those perceived norms by participating in male intergenerational sexual and social relationships. ${ }^{3}$ It is difficult to understand why these issues have been denied or suppressed, but Diane Wolfthal offers the proposal that: 'it could be part of an outgrowth of the long-standing desire to view art as the embodiment of noble human

\footnotetext{
${ }^{1}$ The Oxford English Dictionary defines pederasty as 'homosexual relations between a man and boy: homosexual anal intercourse, usually with a boy or younger man as the passive partner'. However, the Encyclopaedia of Homosexuality offers a more accurate definition: 'Pederasty is the erotic relationship between an adult male and a boy, generally one between the ages of twelve and seventeen, in which the older partner is attracted to the younger one who returns his affection, whether or not the liaison leads to overt sexual contact' (http://www.williamapercy.com/wiki/index.php/).

2 For information on the fundamental mores and social configurations of same-sex erotic relations in these cultures see Dover, 1978: 81-109; Williams, 1999: 17-19; and Rocke, 1996: 87-101.

3 The singularly most informative and pioneering study of the theme of homoerotic art using mythological subject matter largely limited to the Ganymede topos is Saslow's Ganymede in the Renaissance: Homosexuality in Art and Society (1986).
} 
action or as the expression of the highest and purest ideals. Sexual desire and activity, by contrast, were all too often deemed base or evil, and so ignored' (Wolfthal, 2010: 4).

Unlike Renaissance Italy and classical Greece, pederasty does not necessarily fit into our habitual categories of understanding ageasymmetrical sexual relationships, and men who characteristically prefer relations with youths are considered in our society deserving of sanction, if not outright condemnation. But in these past cultures, this type of social and sexual activity was often seen as an educational institution for the inculcation of moral and cultural values by the older man to the younger, as well as a form of sexual expression. In fact, pederastic relations were often considered to be a transient and natural stage in the lives of both adults and youths (Percy, 1996: 1). However, as perspicacious readings of ancient Greek sources reveal, the erasteseromenos relationship was based upon dyadic mentorship fundamental to that culture's social and educational system (Dover, 1978: 88-91). Moreover, as Halperin explains, these acts were governed by strict social rules and etiquette:

Active and passive sexual roles are necessarily isomorphic with superordinate and subordinate social status; hence, an adult male citizen of Athens can have legitimate sexual relations only with statutory minors (his inferiors not in age but in social and political status); the proper targets of his sexual desire include, specifically, women, boys, foreigners, and slaves-all of them persons who do not enjoy the same legal and political rights and privileges that he does. Furthermore, what a citizen does in bed reflects the differential in status that distinguishes him from his sexual partner: the citizen's superior prestige and authority express themselves in his sexual precedence and in his power to initiate a sexual act, his right to obtain pleasure from it, and his assumption of an insertive rather than a receptive sexual role. (Halperin, 1990: 30-31)

The Renaissance itself was a period that was notably concerned with the relationship between the written and the visual. Myths were often fictional stories told in ancient cultures to explain a practice, belief, or natural occurrence even if they were unproven. The rediscovery of these exciting narratives, as well as other classical texts, had an intense effect on the Renaissance intellect causing a profound transformation in Italian 
culture. ${ }^{4}$ Fuelled in large part by these stories, the Renaissance imagination became endowed with a pantheon of divinities and heroes a catalogue of licentious images, and a set of erotic references by which deviance and desire could be encoded into contemporary experiences. ${ }^{5}$ Consequently, art which captured this special resonance between a mythical account and visual object enjoyed wildfire popularity. Themes of male same-sex love taken from Ovid's Metamorphoses imparted a paradigmatic narrative currency that was transmitted across time by depicting how love and sex in a variety of forms was supremely important to the gods. Therefore visual rendition of mythological narratives such as those found in Metamorphoses, became common analogies to express the virtues of elegiac, sexual desire and endless tragic love.

For some artists and their patrons, new interest in a sensuous and sensual world where pagan deities indulged in cruelty, mischief and promiscuity brought an ennobling reference. Classical texts could be appropriated less as historical documents than as works, adapted or distorted, to voice their own interests, perspectives, and anxieties-even when the sexual activities of pagan protagonists existed, sometimes uneasily, alongside the official symbols and doctrines of the Church. Two works of art which signify how mythological narratives were enmeshed with Renaissance attitudes toward intergenerational male same-sex behaviour and its attendant ideological complexities are Benvenuto Cellini's marble sculpture of Apollo and Hyacinth (1545-48) and Giulio Romano's drawing of Apollo and Cyparissus (1524).

\footnotetext{
${ }^{4}$ For an informative account of the reception of mythology in the Italian Renaissance, see Bull, 2005: 7-36; and Barkan, 1991: 10-18.

5 The most influential text for dissemination of mythography in the Renaissance was Giovanni Boccaccio, Genealogia Deorum Gentilium (On the Genealogy of the Gods of the Gentiles), 1360 revised up to 1374 . Other versions to appear in the sixteenth century were Lilio Gregorio Giraldi, De deis gentium varia et multiplex historia in qua simul de eorum imaginibus et cognominibus agitur (On the History of Pagan Gods in Which Their Images and Cognates Are Dealt with), Basel, 1548; Natale Conti, Mythologiae sive explicationis fabularum libri decem (On Mythology or on the Explanation of Fables), Venice, 1551; Vincenzo Cartari, Le imagini colla sposizione degli dei degli antichi (The Images with Explanations of the Gods of the Ancients), Venice, 1556
} 


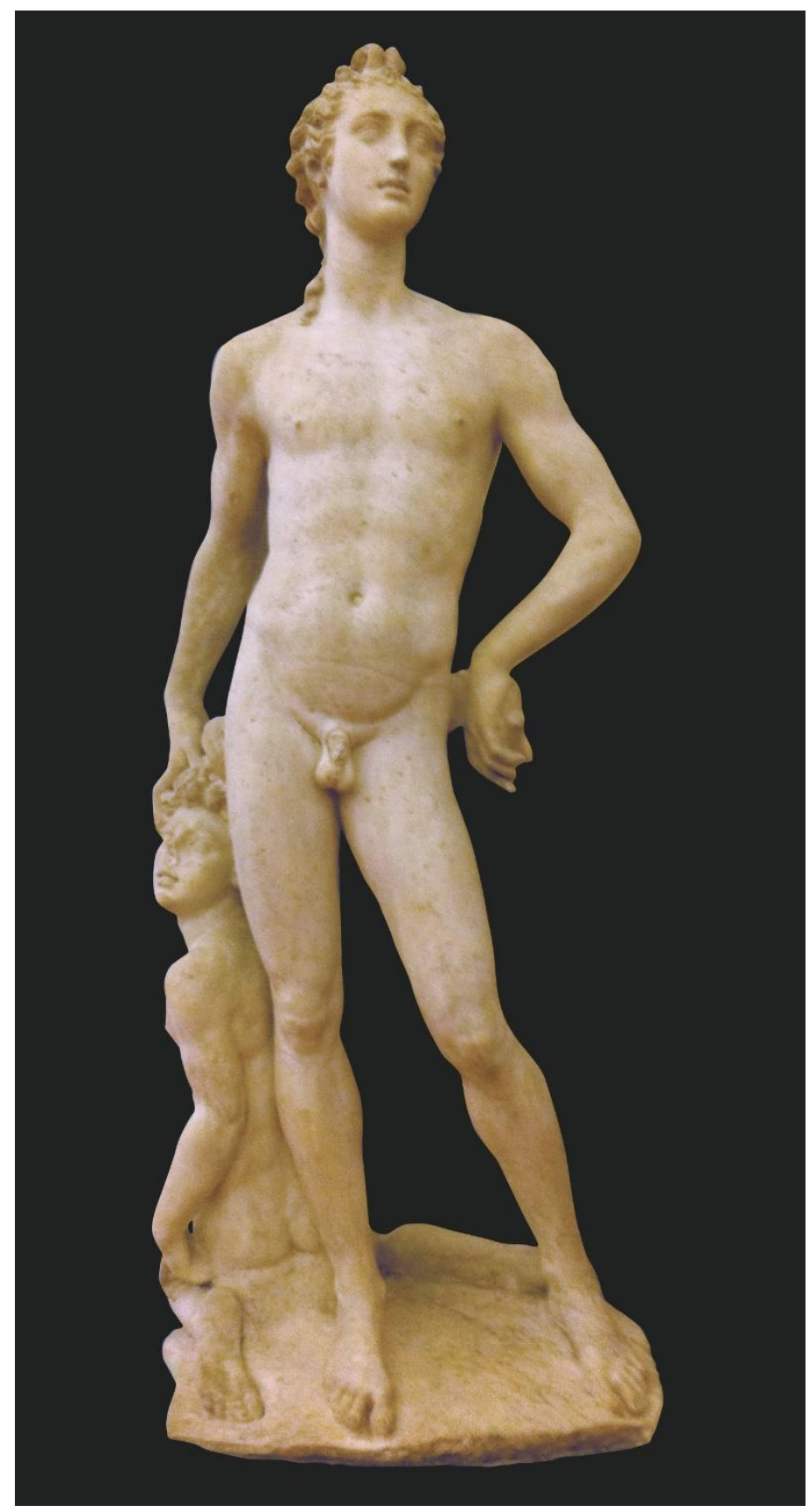

Figure 1. Benvenuto Cellini, Apollo and Hyacinth (1545-48). Marble, Museo Nazionale del Bargello, Florence. 


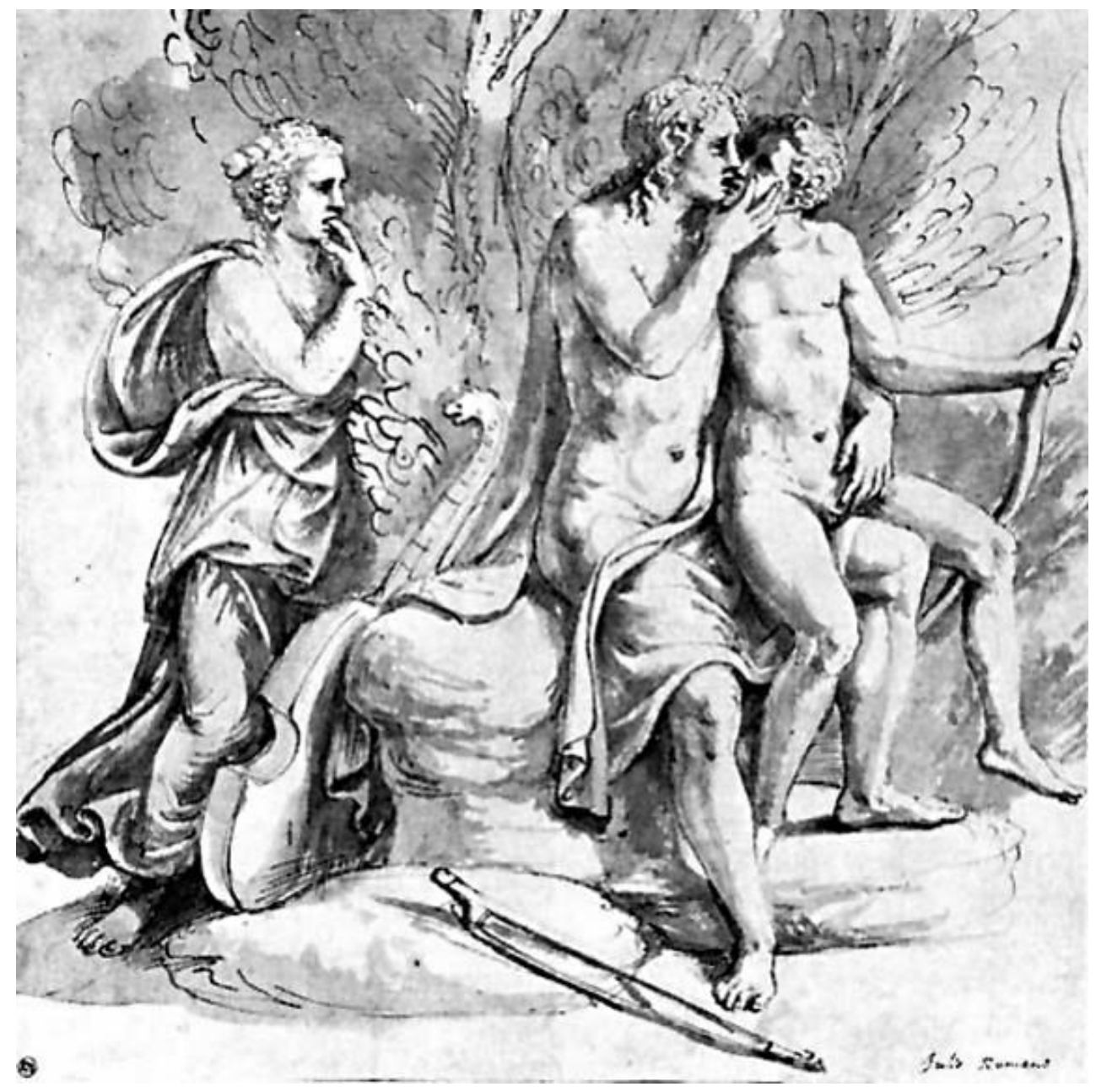

Figure 2. Giulio Romano, Apollo and Cyparissus (c.1523-27). Pen and ink with wash, National Museum, Stockholm.

As pederastic models of the superordinate adult Apollo with his subordinate adolescent male beloveds, these works exemplify how the sexual behaviour and experience which prevailed between ageasymmetrical males in the Renaissance, as well as the psychological meanings, patterns and identities assigned to those acts, found expression in the visual domain of the period. Yet, to date, the encoded messages within both these images have been studied only in the most cursory fashion.

By taking as its departure point Michael Rocke's research into the denunciations, sentencing and interrogations revealed in extant fifteenth-century Florentine judicial records, together with a detailed analysis of these works of art, this article aims to reveal a fascinating insight into visual culture beyond the current conventional limited and limiting heterosexual or feminist biased art historical discourse. ${ }^{6}$ It will

\footnotetext{
${ }^{6}$ Useful examples of feminist approaches to gender in art history include Pollock, 1988; Bartkey, 1991. The relationship between mythology and the erotic in a heterosexual context is the focus of Talvacchia, 1991.
} 
also maintain that it is critically important to open our minds to the understanding of works of art which appear to reflect the attitudes, sexual specificities and historical contingencies of, not just Renaissance Italy, but any given period in the past. Only then, I will argue, can new questions surface about the responses such artworks engendered through the messages they expressed, and only then will we gain a closer understanding of a range of visual codes and embodied responses involved in their execution, reception and articulation.

By situating these works both thematically and compositionally alongside contemporary behavioural codes of masculine sexual and social comportment, the study to follow will consider each as the articulation of Renaissance power dynamics, differentials and constructs. Furthermore, it will offer a more nuanced study and reappraisal of the allegorical and iconographic elements encapsulated in these works, in order to encourage closer engagement with how such imagery depicting myths of male love could function in Renaissance visual and political culture.

\section{Social and cultural contexts}

In his pioneering study of the social history of sexual conduct between males, Michael Rocke informs us in Forbidden Friendships that sodomy in general, and particularly its prosecution, was well-documented in Renaissance Florence. ${ }^{7}$ Of particular note is the extent to which pederastic relationships emerge with vigour in Florence's legislative records. Rocke's research into the records used by the magistracy founded in 1432 to investigate and prosecute offenders accused of sodomy suggests that cultural and sexual norms operated within a strict hierarchy where equality was detested (Rocke, 1996: 4-14).

Sex between males did not preclude sex with females but a youth who was submissive and allowed themselves to be sodomised was regarded as just as inferior as a woman. Rocke lucidly illustrates that during this seventy-year period a lurid sexual culture existed where these same-sex acts were not the divergent transgressions of a marginal minority, but an integral facet of masculine behaviour (Rocke, 1996: 45-84). At a time when lived eroticism conformed to rules of social hierarchy with sexual roles tied to age as well as class, in a virile society such as Renaissance Florence, subjugation, domination and the imposition of one's will were considered defining characteristics. The importance of adherence to prescribed gender roles was paramount, therefore how men behaved

\footnotetext{
7 In addition to Rocke's research, an account of sodomy in the Italian Renaissance can be located in Finucci, 2003: 249-50; Dinshaw, 1999: 55-79; O'Donnell and O’Rourke, 2002: 99-103.
} 
sexually contributed fundamentally to the shape of public life in a broader sense (Mazo-Karras, 2003: 3-8; Rocke, 1996: 87-111).

In common with the cultures of ancient Greece and Rome, Renaissance sexual ethics and behaviour were governed not by the heterohomosexual context but by the question of active-passive roles that were enmeshed with important comportmental codes associated with these hierarchal stratifications. This view is shared by Foucault in his seminal philosophy on the history of sexuality, where he states that classical antiquity 'did not classify sexual conduct according to sex, but according to social class and the categories of activity and passivity' (Foucault, 1978: 1-14).

Nevertheless, these male erotic interactions faced fervent ecclesiastical and theological proscriptions with Domenico of Prato (1389-1432) pointing to the long standing prevalence of pederasty in court circles: 'those marvellous competitions of fencing, tournaments and high jousts are no longer furiously performed for women; he who best can, now does his shows for young lads' (Segre, 1892: 4-85). San Bernardino of Sienna expressed concern that these male relationships were a threat to marriage: 'Woe to him who doesn't take a wife when he has the time and a legitimate reason! For remaining single they become sodomites. And take this as a general rule. When you see a man the right age and in good health who doesn't take a wife, take it as a bad sign about him, if he hasn't been practising chastity for spiritual reasons' (Bernardino, 1989).

The tension that existed between Renaissance Italian judicial and religious prohibition and commonplace behaviour made it a public affair. Therefore, as Rocke informs us, where sexual activity between men was expected to be temporary and cyclical, there were harsher penalties levied upon adults who continue homoerotic activities with those who are beyond youth. Rocke has estimated that at least two-thirds of all Florentine males were implicated by the time they reached the age of forty, and these figures do not include the magistracies themselves: 'at one time or another and with varying significance and degrees of involvement, pederastic relations formed part of the life experience of many Italian males of the late medieval and early modern period' (Rocke, 1996: 15). It was considered degrading to remain a passive agent once a grown man, therefore only as long as the passive partner were a boy could he expect leniency.

The significance of the information Rocke has gleaned from these judicial records for the following interpretation of both the statue of Apollo and Hyacinth and the drawing of Apollo with Cyparissus cannot be overstated. Moreover, any study of the conception and execution of these works of art should not be detached from our understanding of the 
social circumstances under which male homoerotic relations were expressed in Renaissance Florence. If we take this historically and culturally framed juridical visibility of male same-sex relations as a departure point, it is possible to evaluate the complex and convoluted meanings within the narrative of the mythic sources underpinning these works and to decode and contextualise the symbolic messages they contain. It will then become clearer how interpersonal dynamics of male desire and social relationships extended into the field of artistic representation. With recourse to Rocke's aforementioned sociological discourse, I will now explore the extent to which both Cellini's sculptural group of Apollo and Hyacinth and Romano's drawing of Apollo and Cyparissus appear to substantiate these surviving judicial records.

\section{Analysis of Myths and Art Works}

Apollo is placed prominently in Metamorphoses as one of the most important Olympian gods, who as the eternal erastes had the most flagrant and prolific male relationships of all the divinities. ${ }^{8}$ Apollo follows the archetypal antique male model of sexual behaviour in Ovid's text, where most males desired both males and females and acted upon both kinds of desire by having legitimate sexual relations with both sexes. Although divinities such as Apollo frequently and recklessly fell in love with other males, they rarely did so with other male gods or with adult human men; their adoration was usually reserved for the most beautiful of human adolescents. ${ }^{9}$ Apollo's romances with younger males are a popular feature in Renaissance artistic production, thereby promoting the notion of male love being divinely approved with mortal male lovers. Often exalted for their royal bloodline or divine forebears, and bestowed with many similar qualities of beauty and pulchritude to their divine counterparts, these subjects shared both exoticism and otherworldliness; characteristics which invoked considerable interest from the flourishing artistic community and their patrons during the Renaissance.

There are a number of ancient myths conveying the custom of paiderastia as the socially acceptable erotic relationship between a man and a youth. ${ }^{10}$ For example, the myth of Jupiter and Ganymede was very

\footnotetext{
${ }^{8}$ For a definition of the role of ancient Greek gods, see Bremmer and Erskine, 2010: 19-80.

${ }^{9}$ One of the rare tales of love between gods is that of Aphrodite and Ares in Homer, The Odyssey, Book VIII, (Hom. Od. 8.250)

10 The love of young men was a common characteristic of gods in Greek and Roman mythology and it offered a rich field that encompassed not just Apollo and Hyacinth and Apollo and Cyparissus but also Zeus and Ganymede, Achilles and Patrocolus, Orpheus (who turned his passionate attentions to young men after spurning women following the death of Eurydice), Narcissus who rejected Echo in favour of his own, superior beauty, and Salmacis and Hermaphroditus.
} 
popular in Renaissance art and there are over two hundred images still extant today. However, the inveterate womanizer Jupiter is reported to have taken Ganymede as his only masculine love, who as a direct result of this honour became both exemplified and sanctioned as the supreme love of the supreme god, whereas Apollo had more male loves than any other god. In contrast to Ganymede, who was the embodiment of the beloved who was forever loved and desired, Apollo is often depicted as the paradigmatic lover.

In both Cellini's marble sculpture of Apollo and Hyacinth (Figure 1) and Romano's drawing of Apollo and Cyparissus (Figure 2) paramount focus is bestowed on Apollo's dominant role as the accomplished adult, whose role is to act as a consummate initiator to his younger lovers. Textual evidence of the ways in which pederasty pervaded sexual and social relations between men in classical antiquity can also be found in several classical texts, including Plato's Republic:

It does not become a lover to forget that all adolescents in some sort sting and stir the amorous lover of youth and appear to him deserving of his attention and desirable ... but the euphemistic invention of some lover who can feel no distaste for sallowness when it accompanies the blooming time of youth? And, in short, there is no pretext you do not allege and there is nothing you shrink from saying to justify you in not rejecting any who are in the bloom of their prime. (Plato, 474d-475a)

In Metamorphoses (Ovid Met. X: 171-219), Hyacinth was a beautiful mortal youth, loved equally by the god Apollo and the West Wind Zephyr. Apollo and Hyacinth took turns throwing the discus but when Hyacinth ran to catch the discus thrown by Apollo, he was struck as it fell to the ground, and died. Apollo refused to allow Hades to claim the young man; rather, he made a flower, the hyacinth, from his spilled blood. The tears of Apollo stained the newly formed flower's petals with a sign of his grief. For Ovid's tale of Apollo's neglect of his duties and the tragic demise of his beloved Hyacinth, see Appendix I. 


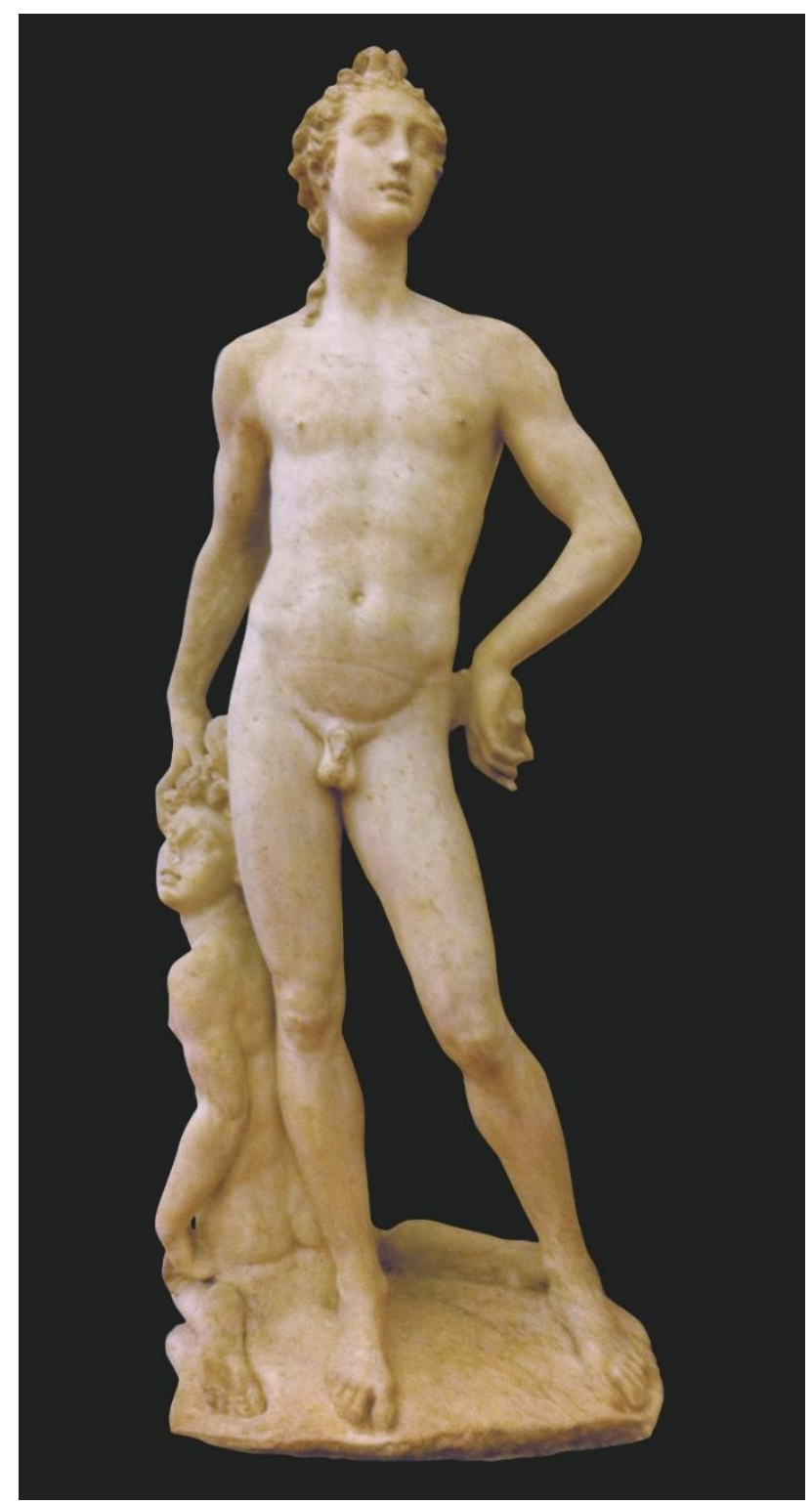

Figure 3. Benvenuto Cellini, Apollo and Hyacinth (1545-48). Marble, Museo Nazionale del Bargello, Florence.

Cellini's sculptural rendition of this Ovidian narrative, as depicted in Figure 3, is executed in white marble and stands $191 \times 75 \mathrm{~cm}$ (Figs. 1ac). ${ }^{11}$ The statue appears to capture the very moment after Hyacinth has been felled by the discus but is yet to transform into his other being. The figure of Apollo is posed with his left leg slightly advanced with its foot on the corner of the base and his right leg erect. His right hand reaches back,

\footnotetext{
${ }^{11}$ The standard monograph of Cellini remains J. Pope-Hennessy Cellini, 1985 which integrates a discussion of a variety of textual sources with the artist's surviving works. This author's approach to Apollo and Hyacinth has much to commend it since he provides a full description of the work together with an informative account of Cellini's tumultuous life. Absent from this otherwise comprehensive study, however, is any discussion of the homoerotic allure of both the sculpture and the Ovidian source of its subject. One of the most recent and inquiring studies of Cellini's oeuvre is Michael Cole's Cellini and the Principles of Sculpture, 2005. However, this author's observations on Apollo and Hyacinth are largely limited to Cellini's occupational circumstances and professional trajectory (Pope-Hennessy, 1985: 83-85).
} 
caressing the hair of the kneeling and significantly smaller Hyacinth. The figure of Hyacinth is positioned slightly behind that of Apollo with his torso turned in the opposite direction, but with his head pivoting backwards and upwards over the left shoulder. The boy's right and left legs are respectively extended behind and along the base and the left side of the work. With the exception of a diadem or Phrygian cap, Apollo is naked, as is Hyacinth. Both figures have elaborately carved curled hairstyles in the classical tradition. Apollo faces away from Hyacinth as if gazing into the distance, whilst Hyacinth is posed with his half open mouth displaying sensuous, full and parted lips almost adjacent to Apollo's groin. Apollo's left wrist rests on his thigh, and in this hand he holds a broken object, possibly part of the discus. The fingers of Hyacinth's left hand are badly damaged but Hyacinth's right hand reaches upwards with fingers touching Apollo's buttocks and his wrist is clasped around an object that seems to be a branch or root of a plant.

According to the other myth from Ovid's Metamorphoses under discussion here, Cyparissus was also a beloved young mortal, but one to whom Apollo bequeathed a beautiful tame stag (Ovid Met. X 81-154). When Cyparissus accidently killed this stag whilst he was being educated in the art of hunting by his lover Apollo, he was distraught by his loss. All of the god's consolations were in vain and Cyparissus was so distressed that he begged to be allowed to mourn forever. Eventually Apollo obliged by turning him into a cypress tree, which appears to be sad because of the droplets of sap that form on its trunk. For Ovid's narrative concerning Apollo's love for Cyparissus, see Appendix II. 


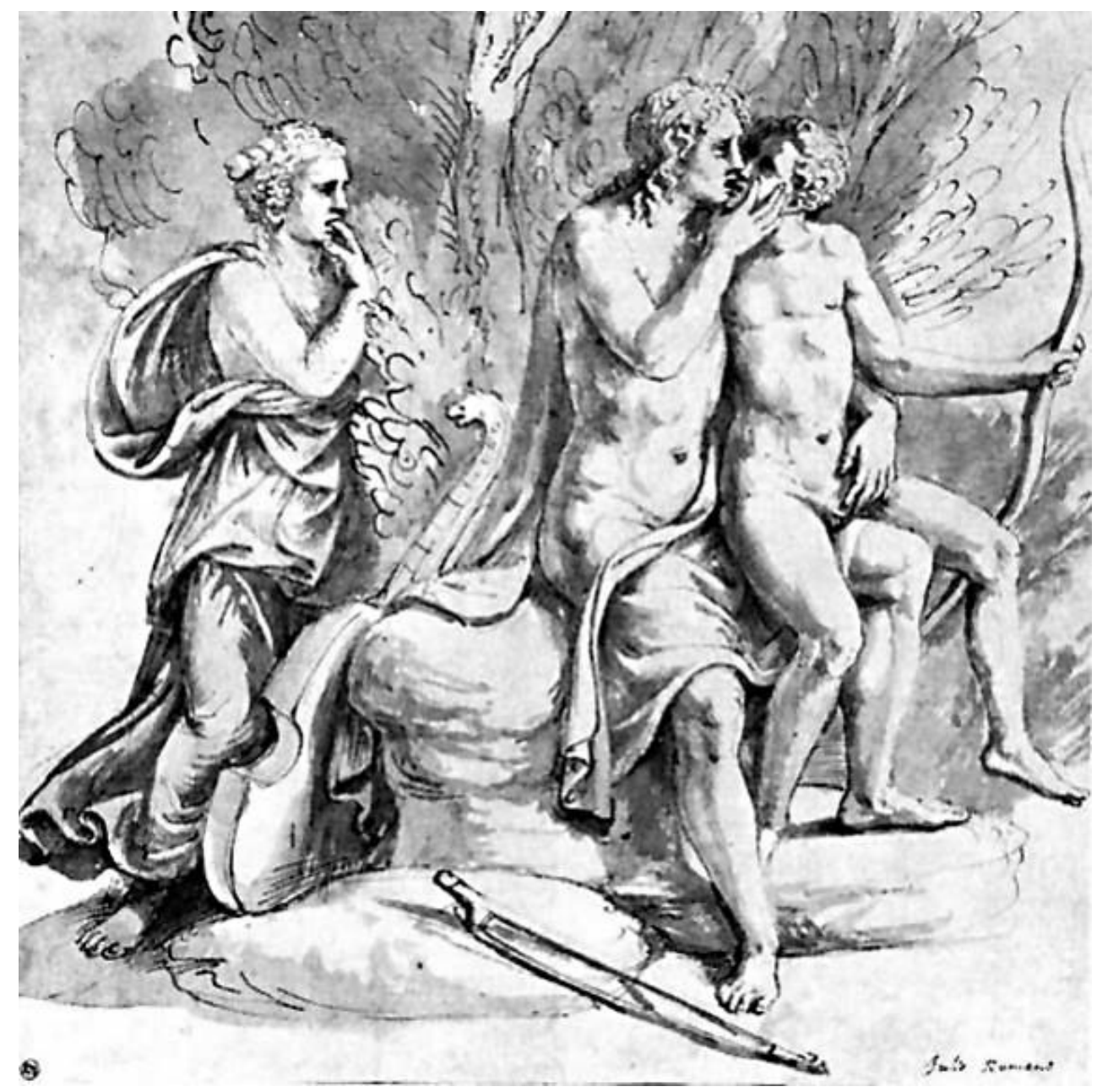

Figure 4. Giulio Romano, Apollo and Cyparissus (c.1523-27). Pen and ink with wash, National Museum, Stockholm.

Giulio Romano's drawing of Ovid's tale of Apollo and Cyparissus appears to be the original and there are no known extant engravings (Figure 4). The provenance and dating of the original work are both inconclusive but Vasari mentions that before he left Rome in 1524, Giulio designed the scene for his friend and financial consultant Baldassarre Turini's Villa Lante (Vasari, 1999: 133-38). The scene depicts an older seated and cloaked Apollo with a nude juvenile Cyparissus on his lap. Apollo's right hand touches the youth's face whilst their lips meet in a kiss. Apollo's left hand is placed in Cyparissus' groin and the index finger seems to touch the boy's penis. The fabric of Apollo's garment separates the two figures as Cyparissus straddles his left knee. Apollo's legs are spread with feet placed on the ground. The youth's right foot is also placed on the ground but the left is raised. Cyparissus holds an upright archer's bow in his left hand, whilst a musical bow lies abandoned in the foreground of the composition. The stringed musical instrument that the bow would accompany leans neglected against the rock on which the pair are seated. The neck of the rock terminates in a carving of a serpent's head, 
pointing in the direction of a clothed and classically draped female onlooker to the far right of the composition. This female figure inserts her left index finger in her mouth as she covertly witnesses their embrace. Her expression is ambiguous but there is little indication of shock or outrage. All the protagonists are positioned in the middle ground but there is a large tree dividing the central background.

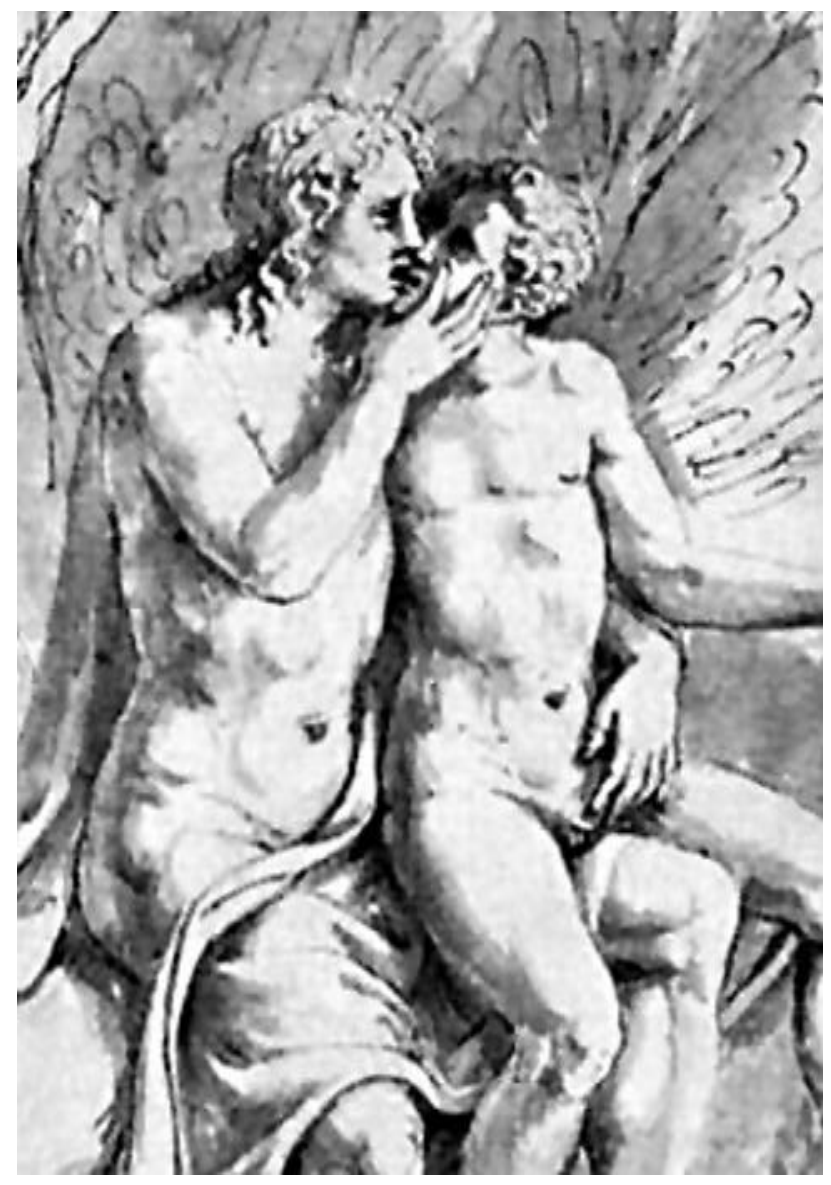

Figure 5. Apollo's hand touching Cyparissus' penis, detail of Apollo and Cyparissus.

It is my own contention that both Cellini and Romano chose Ovid's poems narrating these myths as specific subjects for their respective works because they address the transition from, or death of, youth within a pederastic context. Absolutely fundamental to my analysis of the Apollo and Hyacinth statue and the drawing of Apollo and Cyparissus is the proposition that in these two representations of Apollo with his young lovers, Hyacinth and Cyparissus do not literally transform into botanical entities as such. I instead argue that these youths who die as juveniles at the hands of Apollo, now await not literal metamorphosis into flowers or trees but accession to adulthood. In the following passages, I will elucidate how each artist's interpretation of these myths 
provides a structured initiatory and pedagogical model connected to rites that mark the passage from youth to adulthood. ${ }^{12}$

\section{Apollo and Hyacinth by Benvenuto Cellini (1545-48)}

Firstly, we will focus on the statute of Apollo and Hyacinth (Figure 1), which was Cellini's first foray into sculpture from metallurgy. As a mythic paradigm of ideal masculine behaviour, Cellini's sculpture is a rich source for understanding broader issues relating to contemporary matters concerning identity, gender and sexuality, such as power dynamics and behavioural codes. Upon Cellini's death, twenty-five years after its execution, this almost completed statue was one of three works found in his workshop, along with his sculptures of Ganymede and Narcissus. ${ }^{13}$ In his Vita the artist reveals that the marble block was assigned to him by Duke Cosimo I de' Medici (1537-69) after a public altercation with his rival Baccio Bandinelli (1493-1560), but there is no extant contractual evidence to substantiate it as a firm commission. All we know is that under command from Cosimo, Bandinelli was commanded to give up the marble after accusing Cellini of being 'a dirty sodomite' (Cellini, 1995: 338).

Cellini's masculinity is expressed in his art and it is also known from his Vita that he did not have an exclusive preference for women. The sexual horizon against which Cellini himself moved is personified in the way his writings are permeated with violent boasting and transgressive behaviour, including celebration of the joys and omnipresence of sodomy. One likely reason that Apollo and Hyacinth remained in Cellini's possession without a purchase from Cosimo, is the artist's conviction for sodomy in 1557. One important indicator of the personal significance Apollo and Hyacinth held for Cellini, which has been previously disregarded in published commentaries on the group, is its mention in a sonnet he wrote whilst in prison for this offence:

Oh Phoebus, you know well that the first art did that which all agree is healthiest, for reciprocal love is a human thing, and it distribute seven sweeter virtues. Your fleeing Daphne unhappily shares the never healing wound with your beautiful Hyacinth, she who, for great error, keeps

\footnotetext{
12 For an anthropological survey of initiation ceremonies and rites of passage, see Gennup, 1960: 1-14.

13 The fact that Cellini references beautiful youths from Ovid's Narcissus and Ganymede myths for these two sculptures confirms his interest in the Metamorphoses.
} 
to herself, away from all, and who shares her flowers and fronds with many people.

Worry no longer over who she may give such things, for you have given away the arrows the bow and the lyre; nor do you want anyone to steal them from you. Those little boys are sour and harsh to me, for they, along with time, have drained me of my strength; my third flame is in this great dark dwelling place. (Cellini, 1995: 338)

It is my contention that, given his personal erotic propenstities, Cellini might have used the pederastic Ovidian mythological narrative of Apollo's doomed love for Hyacinth, with all its analogies of prowess and pathos, to make implicit claims about the importance he placed on male sexual relationships in his own life. But Cellini's statue should not be seen solely as an illustration or reflection of a text or a textual tradition because it offers insights into the broader workings of Renaissance Florence, as well as its male culture of public and private, fraternal, filial and sexual affections that drew men together and determined their political culture.

Examination of the compositional intricacies at play within Apollo and Hyacinth indicate that the work seems to possess a broad but specific range of prescriptive behaviours, fundamental to both the social and sexual situations of an age when manliness and honour were inextricably enmeshed with social identity and public reputation. Cellini uses figural stasis and compositional dynamism in the manner he appropriates and modulates the basic contrapposto pose of Apollo who adopts a dominant stance over the acquiescent Hyacinth kneeling in subjugation at his feet. The juvenile boy Hyacinth is almost rooted to the ground in subordination to his mentor and lover, thereby visually informing and communicating recognised cultural parameters and norms relating to old / young, active / passive, masculine / feminine and master / servant roles. 


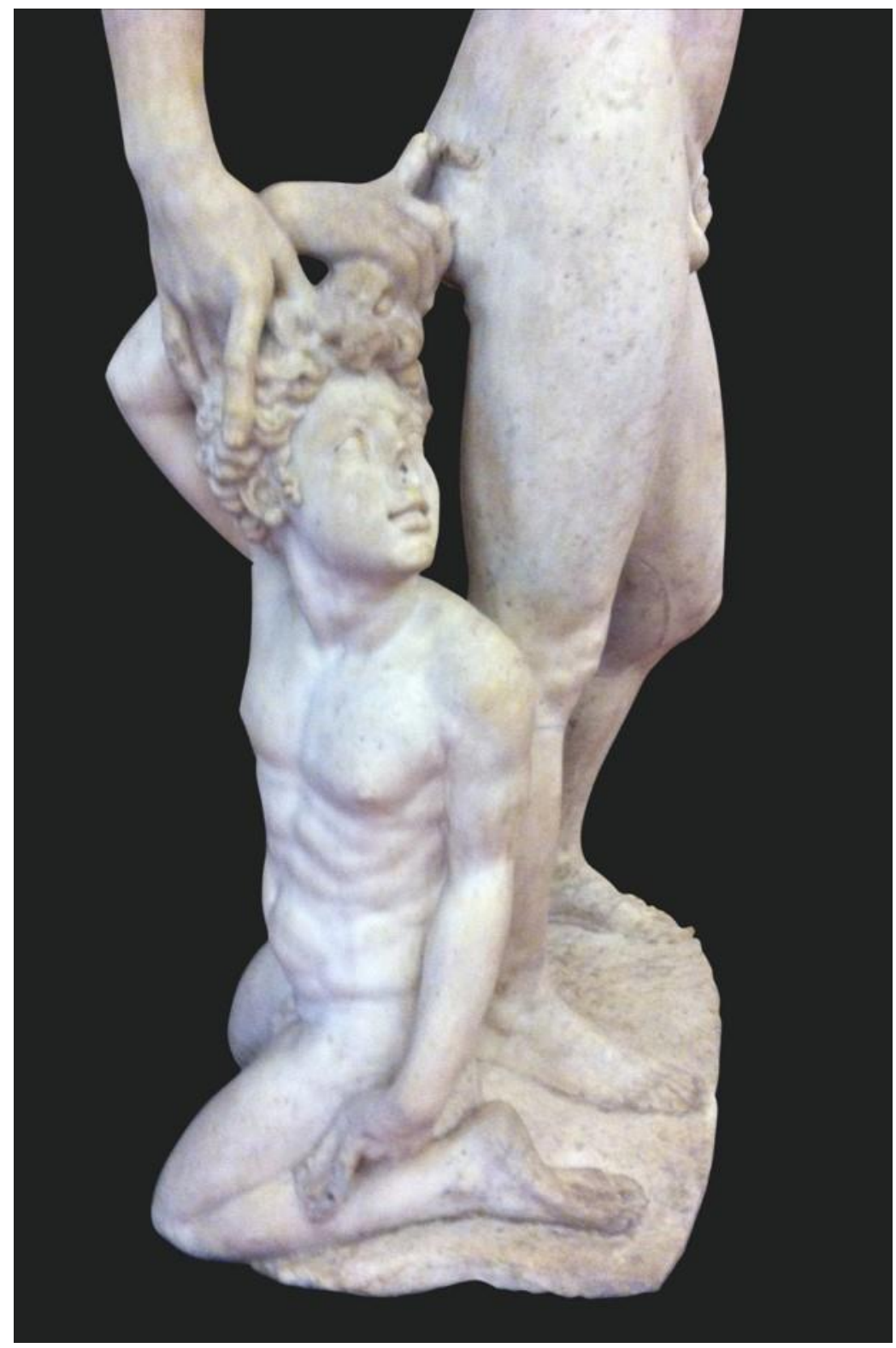

Figure 6. Hyacinth kneeling, detail of Apollo and Hyacinth .

By bringing to the fore the performative aspect of the work, Cellini positions the kneeling Hyacinth behind rather than in front, or even at the side of his master and mentor, in a manner that consciously affirms dominant gender constructs and power dynamics. Apollo and Hyacinth invokes the notion that far from being a mutual experience, sexual activity always had a directional quality for males from both antiquity and the Italian Renaissance. In doing so, he captures a difference in emotions between Apollo and Hyacinth, which recalls those that Xenophon records in his Symposium: 'the boy does not share in a man's pleasure in intercourse; cold sober, he looks upon the other drunk with sexual desire' (Xenophon, Symposium, 8.21, cited in Dover, 1978: 52). Cellini reiterates this when, in contrast to the developed physique of the adult Apollo who stares straight ahead, he presents a kneeling pre- 
pubescent Hyacinth as a passive, reluctant, unaroused youth who is granted favour without any sign of sexual delectation whilst gazing adoringly up at his mentor and lover.

These possibilities are bound up with Ovid's story of Apollo and Hyacinth, as well as the sociological prevalence of sodomy that Rocke's findings uphold. Such signifying elements lend support to the premise that Hyacinth's life ends as a juvenile at this moment and he awaits not literal metamorphosis into a flower, but his accession to adulthood. I suggest that the youth's death should be understood in terms of an archetypal rite of passage since it does not symbolise a real, biological death, but rather it expresses the death of his adolescence. It is possible that Cellini alludes to this proposition when he poses Apollo as if turning away from his beloved in a manner that suggests that because Hyacinth is now transforming from his being as an adolescent into an adult, it is time to take his leave. Therefore, we might read Cellini's depiction of heroism, death and pathos as capturing ritualized male love and honouring the intrinsic significance of same-sex relationships with the visual validation that a love directed at members of one's own sex is true of the gods as well.

Cellini was operating at a time when principal interest in pederasty was viewed as phallic confirmation of the socio-political supremacy of adult citizen males, with each partner taking, expected to take, and wishing to be perceived as taking a prescribed role. Therefore, we can suppose that he recognized the need to render Apollo and Hyacinth in a manner which spoke to the question of those dominant definitions of an active / passive binary. We can glean how much weight the artist gave to this association in the manner in which he renders Hyacinth as the construction and reaffirmation of passivity since he is portrayed as the penetrable and powerless partner whilst Apollo is the male embodiment of virile power in his role as the active, impenetrable and powerful older agent. Cellini celebrates an intensely erotic relationship between Apollo and Hyacinth and thus sets Florentine political sentiments of power and hegemony within an amorous and allegorical register. Nevertheless, the group conveys a codified message that tolerance of erotic activity between men depended on whether expression of these relations violated culturally defined and accepted conventions. 


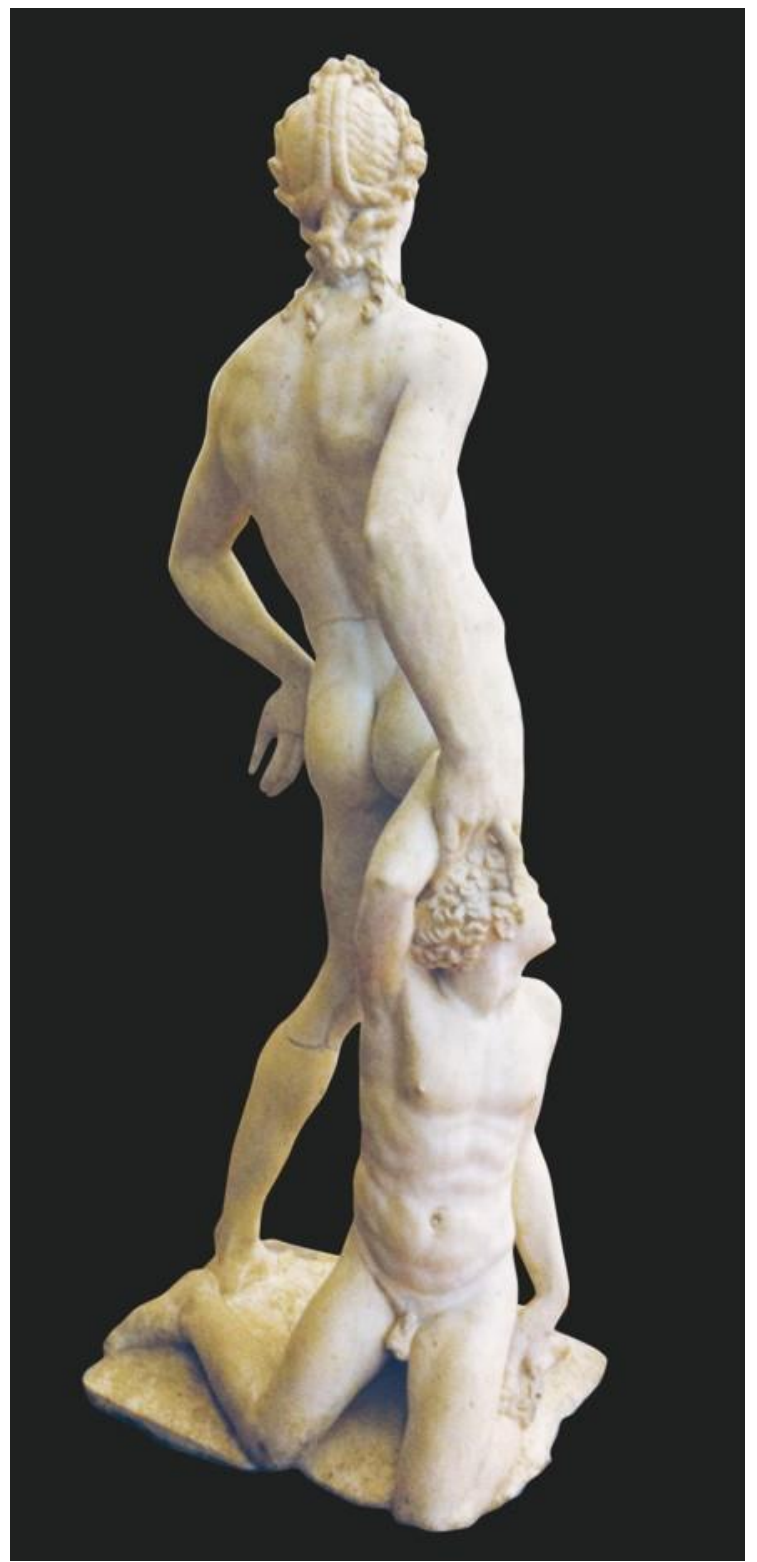

Figure 7. Apollo and Hyacinth (Rear view). Marble, Museo Nazionale del Bargello, Florence.

One of the most homoerotic signifiers in Cellini's composition must surely be the way the artist anticipates an act of oral gratification when he poses Hyacinth with sensuously parted lips knelt at Apollo's feet with his head closely aligned as if turning towards the older agent's groin. The homoerotic character of the group is further augmented in the way that Hyacinth strokes Apollo's buttocks with his right finger. The same hand grasps a phallic shaped object, perhaps a branch to signify his forthcoming metamorphosis, in a manner that suggests a masturbatory act. At a cursory glance, the gesture of Apollo's hand on the youth's head might be viewed as an innocent token of affection. But such a reductive interpretation only holds currency if one reads the subject out of its literary context of homoerotic love, obfuscates Cellini's own male sexual 
impulses and disregards the social and sexual taxonomies revealed in contemporary textual and prosecutorial records. This interrogation of Apollo and Hyacinth has placed the sculpture in relation to the erotic and social milieu that appears to underlay its execution. Moreover, by offering a more comprehensive interpretation of this work we can now situate this depiction of erotic love between a man and a youth within the contexts of public discourses of prevalent contemporary Renaissance sexual activity and its creator's personal libidinal predilections.

\section{Apollo and Cyparissus by Giulio Romano (c.1523-27)}

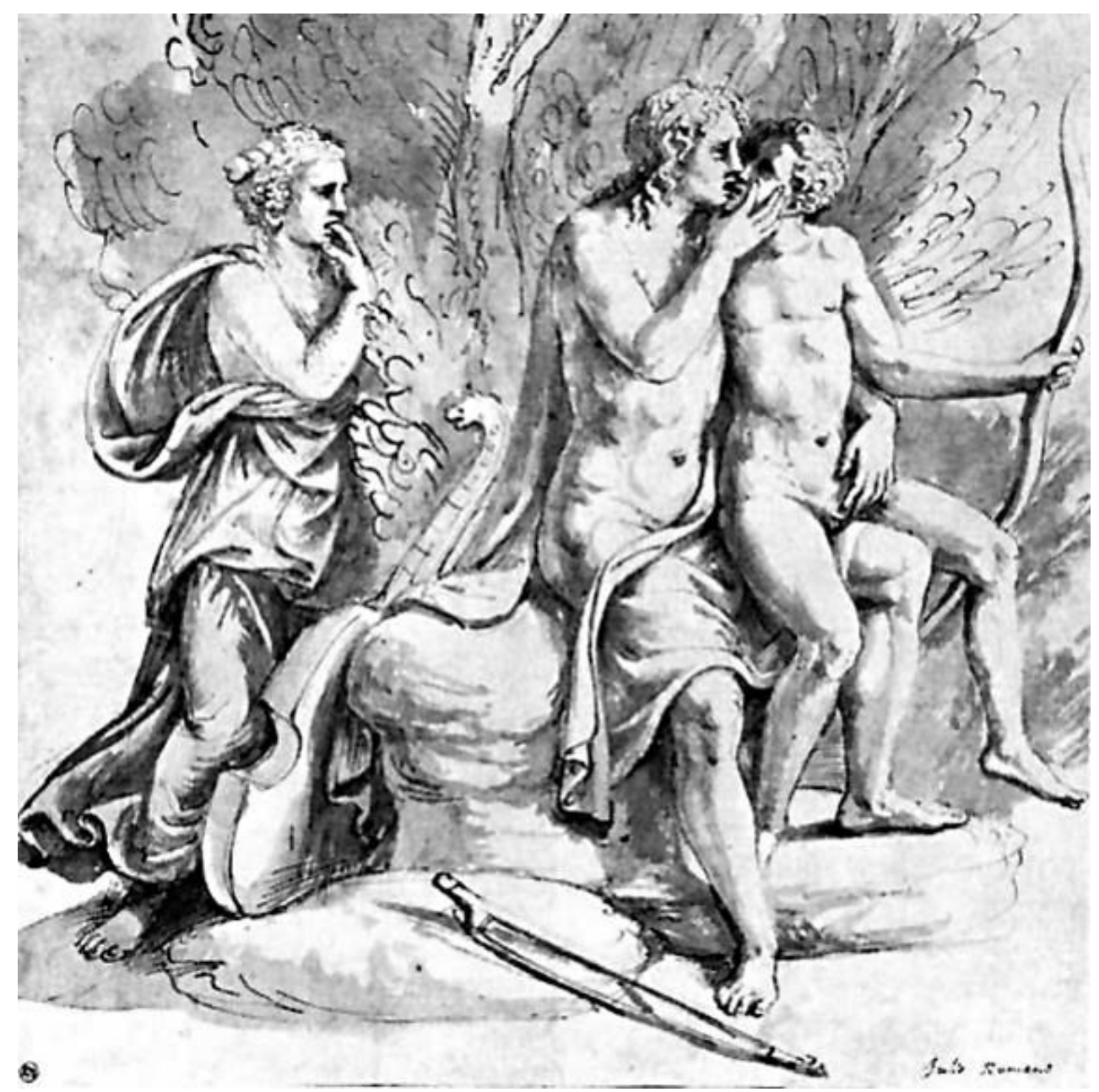

Figure 8. Giulio Romano, Apollo and Cyparissus, c.1523-27. Pen and ink with wash, National Museum, Stockholm.

Giulio Romano's drawing of Apollo and Cyparissus is also distinctively grounded in amorous discourse between an older active agent and his adolescent beloved. Congruent with Cellini's Apollo and Hyacinth, Romano's Apollo and Cyparissus remains consistent with the perception of adult males from the higher classes and their position at the apex of a 
hierarchical social system that privileged patriarchy, age and power. Further examination will explore the extent to which the drawing is congruent with Rocke's statement that: 'intimately related to such concerns about demarcating biological and social stages in life was an equally strong preoccupation about clarifying and reinforcing gender boundaries' (Milner, 2005: 64). It will also consider how representations of pederastic relationships could assume various forms during the Renaissance depending on the medium in which they appeared. This drawing has a contrasting conceptual visualisation and physical execution to Cellini's sculpture of Apollo and Hyacinth. It also exemplifies how there were different iconic ambits in the Renaissance-one private, the other public, and illustrates the extent to which homoerotically charged imagery assumed different faces for private and public consumption.

Whereas the intended audience for Cellini's marble Apollo and Hyacinth would most likely have been diverse and fairly open, Romano's drawing would have been distributed on a private circuit, which was circumscribed and socially elevated. This depiction of male same-sex erotic impulse, albeit in a different medium, equally corresponds with the contemporary stereotypes of masculinity and femininity that took place in the patriarchal society of Renaissance Italy. In Apollo and Cyparissus we find an example of the way in which homoerotic subject matter held a sensual appeal for many patrons from the sophisticated, cultivated ranks of the humanist elite at this time. ${ }^{14}$ However, in order to be considered sufficiently decorous by erudite humanists, rather than irredeemably offensive, a veneer of respectability was needed to be conferred through an obvious and recognisable mythological subject. The classical excursus used in this drawing was particularly important because, by virtue of its transgressive subject and medium, there was the potential for it to become widely disseminated. Consequently, the visibility and identification of homoerotic elements at play in this drawing are heavily veiled in mythological narrative. As Ruggiero explains, erotica in art became less troublesome for the elite if it was endowed with a humanist complexion:

Printmakers adopted themes from antiquity which allowed them to represent naked bodies in suggestive poses with a veneer of intellectual respectability. In a pagan context, nudity, eroticism and the sexual act itself became less troublesome

\footnotetext{
14 There has been only scant scholarly reference to this drawing in past historiography of the artist. Apollo and Cyparissus was included in the 2009 exhibition 'Art and Love in Renaissance Italy' at the Metropolitan Museum of Art in New York and there is short description in the exhibition catalogue, see Wolk-Smith, 2009: 190. For the provenance of the drawing see Hartt, 1958: 252, however, this author omits discussion of the erotic aspect of the drawing. See Talvacchia, 1999: 71-79 for a brief comparison with the artist's heterosexual I Modi drawings.
} 
and somehow more erudite - humanism made lust an intellectual exercise. (Ruggiero, 2010: 5)

In the context of homoerotic imagery it seems that these common practices of engendering sex scenes with mythology were regarded as necessity rather than choice. Romano's drawing of male intergenerational love acknowledges this requirement to veil the homoeroticism in the humanistic gloss of the mythological narrative in a similar way to Cellini's Apollo and Hyacinth. Closer examination of Romano's Apollo and Cyparissus will enable placement of this image at the intersection of modes of Renaissance thought where myth and sexual desire for other males were considerations that were likewise mapped together in art.

In similarity to Cellini's sculpture, Romano's drawing is based on Ovid's narrative poem Metamorphoses, but the literary presentation of this myth, on this occasion, has the younger agent transforming into a cypress tree rather than a flowering plant. Seeming to take the moment when Apollo grants Cyparissus his wish to grieve forever for his beloved stag, and just before his transformation into another life form, Romano depicts Apollo fondly, and perhaps passionately, kissing the adolescent juvenile Cyparissus on the lips whilst fondling his genitals. Gift giving was a pervasive principle and practice between male lovers and their beloveds in ancient Greek society, and one that was manifested in nearly all aspects of life (Dover, 1978: 82-83).

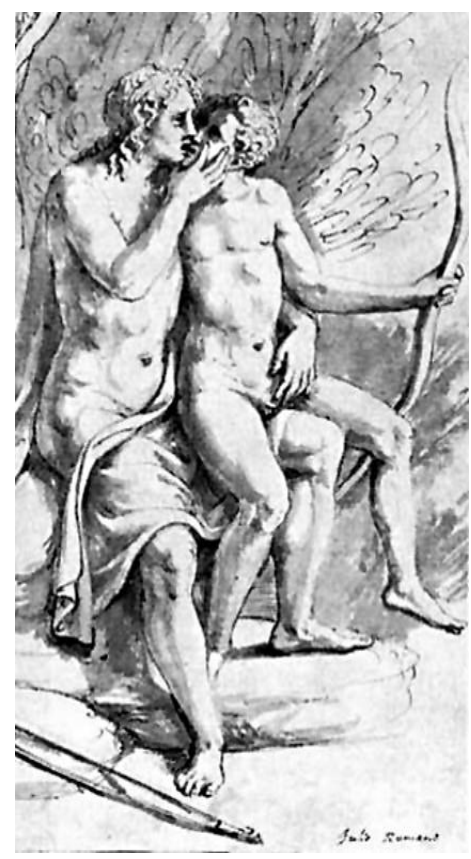

Figure 9. Cyparissus grasping bow, detail of Apollo and Cyparissus. 
In this instance, I believe Apollo's gift of a stag for the adolescent Cyparissus can be understood allegorically as the god's recognition that his young lover is approaching maturity and ready for adulthood. In a way that deviates from the Ovidian story, Romano depicts the younger Cyparissus holding in his left hand not a javelin but an archer's bow as the weapon which fatally wounded his beloved stag. Hunting was a common metaphor for sexual prowess in both Greek and Renaissance cultures where the symbolic significance of shooting a bow and arrow had resonance with ejaculation and vital sexual energy. ${ }^{15}$ As Dover states: 'If the quarry is human and the object copulation, the difficulty of the chase enhances the value of the object, and eventual capture, after fierce competition with rival hunters, is incalculably reassuring to himself' (Dover, 1978: 88). In Greek culture, the hunt was more than just an abstract concept. It was among the activities in which young men participated as they were initiated into the civic life of the city (Barringer, 2002: 312-70). The notion that the once hunted Cyparissus, who now holds the bow and is about to become the hunter himself is, to my mind, further indication that Romano is departing here from Ovid's story of his metamorphosis into a tree and instead visually rendering the myth as an allegory of transition into adulthood. Furthermore Romano encodes the image with patriarchal power and categories of masculine virtue in the manner he juxtaposes the naked, idealised beauty of Cyparissus engaged in a sexually suggestive coupling with his paramour Apollo against the formless drapery that envelops the isolated clothed female figure. In accordance with prescribed contemporary gender roles this woman is, and will remain, ostracized from both the physical and spiritual facets of male relationships, regardless of their carnal intent.

The juxtaposition is further developed in the way a large bowed stringed musical instrument is positioned precariously leaning against the rock. Interestingly, Romano includes a contemporary instrument rather than Apollo's trademark ancient lyre. ${ }^{16}$ Its shape is strongly suggestive of feminine characteristics but, significantly, it is presently left neglected by the juvenile Cyparissus. Romano renders his female voyeur devoid of luscious, glorious fleshiness in a manner which eschews the objectifying logic of male gazing and female passivity, but includes instead an instrument which replicates the graceful curves of an idealised womanly form. Romano's placement of both the abandoned stringed instrument and its forsaken musical bow sharply contrasts with the way an erect

\footnotetext{
${ }^{15}$ For a discussion on youths as quarry and the analogy between hunting and pederasty, see Dover, 1978: 86-89. For a detailed account of phallic symbolism and the sexual association of weaponry during the Renaissance, see Simons, 2011: 112-22. Also, Gurven, 2009: 51-73.

16 This musical instrument resembling a cello is likely to be bass viol da gamba which first appeared in the early Renaissance. For an account of the history and use of this instrument, see Woodfield and Brown, 1984.
} 
weapon is grasped in Cyparissus' hand. This emphasis on the male protagonist's erotic activity could be read as a euphemism for neglecting the act of touching, cradling, handling, playing, and caressing the female body in order to emit the desired sounds. In addition, the instrument's neck terminates with a carving of a serpent's head in a way that could be understood as a symbolic allusion to female temptation. This reference to Eve's temptation of Adam in the Garden of Eden finds a parallel in the pastoral setting of Apollo and Cyparissus and is emblematic of a potential threat to masculine virtue by succumbing to female sexual desire. ${ }^{17}$ Romano seems to be suggesting that the woman, playing the part of temptress, could prematurely distract their attention away from the serious business of pederastic pedagogy.

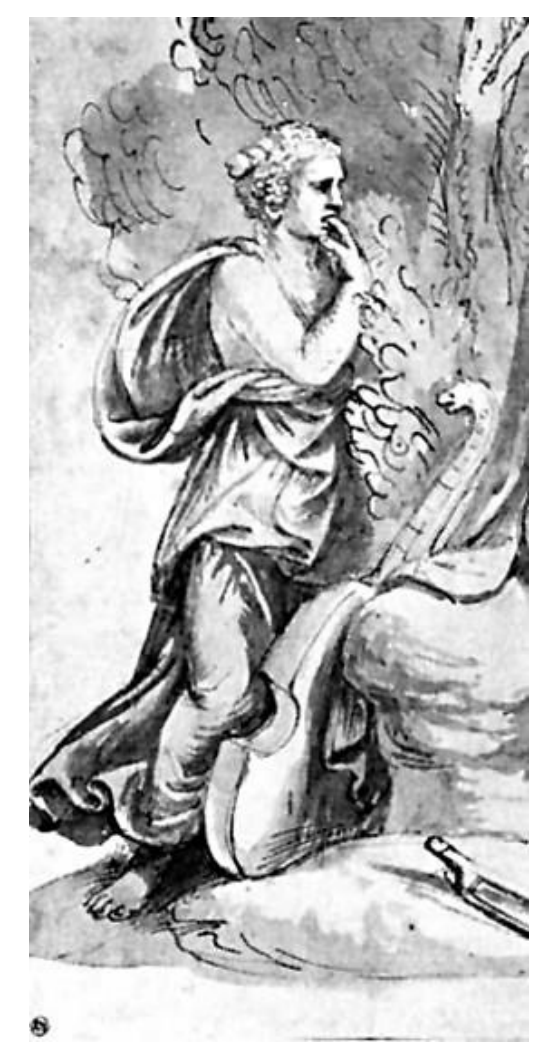

Figure 10. Female voyeur with finger in mouth, detail of Apollo and Cyparissus.

This inclusion of a female voyeur within his composition is one of the most extraordinary features of Romano's Apollo and Cyparissus. Placing a woman voyeur in the same pictorial field is perhaps also forewarning that to cede phallic pleasure to a woman threatens socio-political status since, as G. Servadio's research into Renaissance womanhood explains, sexual desire in women was considered to be a risk to the self-control so central

${ }_{17}$ Genesis 3:13. Renaissance anxieties about the lure of women is discussed in Wolfhal, 2010: 2331. See also Martines, 1974: 15-28. 
to the conception of masculine virtue. ${ }^{18}$ In this manner, Romano appears to make similar implicit claims about the importance of sexual and social roles in the period to those Rocke makes from his research of the judicial archives. As Rocke states, a grown man who exhibited passivity would induce such a contemptuous reaction and be deemed to have behaved so inappropriately that he would be severely penalised 'because it was considered unacceptable masculine behaviour that challenged and threatened to defame the virility not only of the offender himself but of the entire male community' (Milner, 2005: 64). It can be contended, therefore, that this female figure who observes their libidinous union serves to reiterate the expectation that the juvenile Cyparissus would soon be assuming the active role of lover and husband. Just as the main protagonists are men behaving in accordance within codified gender expectations for masculinity, the female also conforms to expected gender roles by silently observing male interaction without intervention in a manner that would have mirrored expected behavioural comportment from an obedient prospective wife.

The manner in which this woman voyeur inserts a finger in her own mouth carries a further analogous meaning that expounds on the sexual theme of the narrative. I would argue that the existence of the female voyeur seems far more nuanced than a gesture of puzzlement or dismay and is more likely to be read as the woman's anticipation of her forthcoming role as the administrator of pleasure for her soon to be adult and marriageable suitor. As if to emphasise that passivity was only acceptable at a certain stage in a man's life, the attendance of this woman together with the phallic symbolism of the temporarily abandoned bow that Romano prominently places in the centre foreground evokes a certain reassurance that once metamorphosis into adulthood as an active procreative being is complete, Cyparissus will return his attention to this more 'natural' form in order to fulfil his own patriarchal and pedagogical obligations. Despite its strong homoerotic overtones, within Romano's drawing a coherent, if complex, picture emerges where it seems that once his metamorphosis is complete, Cyparissus, in line with all juveniles expected to take up their place as erstwhile citizens, will soon marry and sire offspring as a civic and familial duty. I believe that the pederasty we see depicted in Apollo and Cyparissus substantiates the information Rocke has gleaned from the detailed magisterial records where a picture emerges of pederasty as a common but transient phase in an adolescent's life before taking a wife (Rocke, 1996: 14).

\footnotetext{
18 For an account of Renaissance womanhood and contemporary expectations for feminine decorum, see Servadio, 2005: 1-21.
} 


\section{Conclusion}

Past discourse on the Italian Renaissance has been less than alert to the connection between the predication of masculinity in the visual field of male same-sex erotic behaviour and the subject has often been readily overlooked by those who prefer to study the more traditional and canonical aspects of its art and society. Mindful of the fact that no text, visual or written, is comprehensible without a close consideration of contemporary interest and practices, this article has attempted to redress this neglect by adopting a more comprehensive approach to the subject of pederasty in the visual domain of the Italian Renaissance.

In order to situate these case studies within the historical and sexual specificity of their period, it has been necessary to re-evaluate a variety of previously under-theorised factors that might have brought Apollo and Hyacinth and Apollo and Cyparissus into being. In the case of Cellini, a new association has been made between this sculpture and the artist's sexual life. Most significantly, this study has aimed to elucidate the ways in which these artworks bear directly on the matter of codified expectations for manly sexual, gender, social and cultural deportment and concluded that there is a correlation between these artworks, their mythological texts and the social circumstances revealed in the official records.

\section{APPENDIX I:}

No more has he thought for zither or for bow. Entirely heedless of his usual pursuits, he refuses not to bear the nets nor hold the dogs in leash, nor go as comrade along the rough mountain ridges. And so with long association he feeds his passion's flame. And now Titan was about midway 'twixt the coming and the banished night, standing at equal distance from both extremes; they strip themselves and, gleaming with rich olive oil, they try a contest with the broad discus. This well poised Phoebus [Apollo] sent flying through the air and cleft the opposite clouds with the heavy iron. Down again to the solid earth after long time it fell, revealing the hurler's skill and strength combined. Straight away the Taenarian youth, heedless of danger and moved by eagerness for the game, ran out to take up the discus. But the hard earth, returning the flow, hurled it back up full in your face, O Hyacinthus.

The god grows deadly pale even as the boy, and catches up the huddled form; now he seeks to warm you again, now tries to staunch your dreadful wound, now strives to stay your parting soul with healing herbs. But his arts are of no avail; the wound is past all cure... 'Thou art fallen, 
defrauded of thy youth's prime,' says Phoebus, 'and in thy wound do I see my guilt; thou art my cause of grief and self-reproach; my hand must be proclaimed the cause of thy destruction. I am author of thy death. And yet, what is my fault, unless my playing with thee can be called a fault, unless my loving thee can be called a fault? And oh that I might meet death together with thee and might with thee give up my life!

But since we are held from this by the laws of fate, though shalt be always with me, and shall stay mindful on my lips. Thee shall my lyre, struck by my hand, thee shall my songs proclaim. And as a new flower, by thy markings shalt thou imitate my groans. Also the time will come when a most valiant hero shall be linked with this flower, and by the same markings shall he be known'. While Apollo thus spoke with truth-telling lips, behold, the blood which had poured out on the ground and stained the grass, ceased to be blood, and in its place there sprang a flower, brighter than the Tyrian dye. It took the form of the lily, save that it was the one which was of purple hue, while the other was silvery white. Phoebus, not satisfied with this - for 'twas he who wrought the honouring miracle - himself inscribed his grieving words upon the leaves, and the flower bore the marks, $A l$ Al, letters of lamentation, drawn thereon.

(Ovid, Metamorphoses, Book X, lines 170-215, 1977: 77-9) ${ }^{19}$

\section{APPENDIX II:}

Amidst this throng came the cone-shaped cypress, now a tree but once a boy, beloved by that god who strings the lyre and strings the bow. For there was a mighty stag, sacred to the nymphs who haunt the Carthaean plains, whose wide spreading antlers gave ample shade to his own head... It was high noon on a summer's day when the spreading claws of the shore-loving Crab were burning with the sun's hot rays. Weary, the stag had laid down upon the grassy earth and was drinking in the coolness of the forest shade. Him, all unwittingly, the boy Cyparissus, pierced with a sharp javelin, and when he saw him dying of the cruel wound, he resolved on death himself. What did not Phoebus say to comfort him! How he warned him to grieve in moderation and consistently with the occasion! The lad only groaned and begged this as the boon he most desired from heaven, that he might mourn forever. And now, as his life forces were exhausted by endless weeping, his limbs began to change to a green colour, and his locks, which but now overhung his snowy brow, were turned to a bristling crest, and he became a stiff tree with slender

19 This paper uses excerpts from the Loeb translated version of Ovid's epic poem to support its central argumentations 
top looking to the starry heavens. The god groaned and, full of sadness said: 'You shall be mourned by me, shall mourn for others, and your place shall always be where others grieve'...he raised his voice in this song: 'From Jove, O Muse, my mother-for all things yield to the sway of Jove- inspire my song! Oft I have sung of the power of Jove before: I have sung the giants in a heavier strain, and the victorious bolts hurled on the Phlegraean plains. But now I need the gentler touch, for I sing of boys beloved by gods, and maidens inflamed by unnatural love and paying the penalty of their lust.

(Ovid, Metamorphoses, Book X, 1977, lines 81-154: 71-75) 


\section{References}

Barkan, L. (1991), Transuming Passion: Ganymede and the Erotics of Humanism, Stanford: Stanford University Press

Bartkey, S. L. (1991), Femininity and Domination: Studies in the Phenomenology of Oppression (Thinking Gender), London: Routledge

Bayer, A. (ed.) (2009), Art and Love in Renaissance Italy, New Haven and London: Yale University Press

Bernardino of Siena (1989), Prediche volgari sul campo di Siena, 1427, Vol. I, ed. Carlo Delcorno, Milan: Ricerca

Barringer, Judith M. (2002), The Hunt in Ancient Greece, Baltimore: John Hopkins University Press

Bremmer, Jan N. and A. Erskine (2010), The Gods of Ancient Greece: Identities and Transformations, Edinburgh: Edinburgh University Press

Bull, M. (2005), The Mirror of the Gods, London: Penguin

Cellini, B. (1995), La Vita, trans. J. Addington-Symonds, London:

Everyman

Cole, M. (2005), Cellini and the Principles of Sculpture, Cambridge:

Cambridge University Press

Davidson, J. (2007), The Greeks and Greek Love, London: Weidenfeld \& Nicolson

Dinshaw, C. (1999), Getting Medieval: Sexualities and Communities, Preand Postmodern, Durham and London: Duke University Press

Downing, J. (1990), Myths and Mysteries of Same-sex Love, New York: Continuum

Dover, K. J. (1978), Greek Homosexuality, Cambridge, MA: Harvard University Press

Finucci, V. (2003), The Manly Masquerade: Masculinity, Paternity and Castration in the Italian Renaissance, Durham and London: Duke University Press

Foucault, M. (1978), The History of Sexuality: The Will of Knowledge, Vol. 1, trans. R. Hurley, London: Penguin

Gurven, M. (2009), 'Why do men hunt?', Current Anthropology, 50, 5173

Halperin, D. (1990), One Hundred Years of Homosexuality, New York: Routledge 
Hamilton, E., and H. Cairns (eds) (1961), The Collected Dialogues of Plato, Princeton: Princeton University Press

Hartt, F. (1958), Giulio Romano, New Haven: Yale University Press

Homer (1919), The Odyssey, Book VIII, (Hom. Od. 8.250), trans. A.T. Murray, Cambridge, MA., London: Harvard University Press

Ovid (1975), Metamorphoses, Book X, trans. Frank Justus Miller, Cambridge, MA: Harvard University Press

O'Donnell, K. and O'Rourke, M. (2002) Love, Sex, Intimacy and Friendship between Men, 1550-1800, London: Palgrave Macmillan

Lear, A. and Cantarella. E. (2009), Images of Ancient Greek Pederasty, London and New York: Routledge

Martines, L. (1974), 'A Way of Looking at Women in Renaissance Florence', Journal of Medieval and Renaissance Studies, 4 (1), 15-28

Matthews-Grieco, S.F., (ed.) (2010), Erotic Cultures of Renaissance Italy, Farnham: Ashgate

Mazo-Karras, R. (2003), From Boys to Men: Formations of Masculinity in Late Medieval Europe, Philadelphia: University of Pennsylvania Press

Milner, S. J. (ed.) (2005), At the Margins: Minority Groups in Premodern Italy, Minneapolis: University of Minnesota Press

Percy III, W. A. (1996), Pederasty and Pedagogy in Archaic Greece, Urbana: University of Illinois Press

Plato (1961), The Collected Dialogues of Plato, trans. Hamilton and Cairns, Princeton: Princeton University Press

Pollock, G. (1988), Vision and Difference: Feminism, Femininity and Histories of Art, London and New York: Routledge

Pope-Hennessy, J. (1985), Cellini, London: Macmillan

Rocke, M. (1996), Forbidden Friendships: Homosexuality and Male Culture in Renaissance Florence, Oxford: Oxford University Press

Ruggiero, G. (2010), 'Hunting for birds in the Italian Renaissance', in Matthews-Grieco, S. F. (ed.), Erotic Cultures of Renaissance Italy, Farnham: Ashgate

Ruggiero, G. (1985), The Boundaries of Eros: Sex Crime and Sexuality in Renaissance Venice, Oxford: Oxford University Press

Saslow, J. (1989), Hidden from History: Reclaiming the Gay and Lesbian Past, New Haven and London: Yale University Press 
Saslow, J. (1986), Ganymede in the Renaissance: Homosexuality in Art and Society, New Haven and London: Yale University Press

Segre, A. (1892), 'I dispacci di Cristofo da Piacenza, procuratore mantovano alla corte pontificale', Archivia storico italiano, Ser. 5: t.10

Servadio, G. (2005), Renaissance Woman, London and New York: I B Tauris

Simons, P. (2011), The Sex of Men in Premodern Europe, Cambridge: Cambridge University Press

Talvacchia, B. (1991), Taking Positions: On the Erotic in Renaissance Culture, Princeton: Princeton University Press

Van Gennup, A. (1960), The Rites of Passage, London: University of Chicago Press

Vasari, G. (1999), Le Vita de' piu eccellenti pittori, scultori e architettori nelle redazioni dell 1550 e 1568 (trans. G. du C. de Vere), New York: Random House

Williams, C. (1999), Roman Homosexuality: Ideologies of Masculinity in Classical Antiquity, Oxford: Oxford University Press

Woodfield, I. and H. Brown (eds.) (1984), The Early History of the Viol, Cambridge: Cambridge University Press

Wolfthal, D. (2010), In and Out of the Marital Bed: Seeing Sex in Renaissance Europe, New Haven and London: Yale University Press

To cite this article:

Haughton, A. (2015), 'Myths of Male Same-Sex Love in the Art of the Italian Renaissance', Exchanges: The Warwick Research Journal, 3(1), 65-95. Retrieved from: http://exchanges.warwick.ac.uk/index.php/exchanges/article/view/80 